can sometimes be bought and purified, considerable ingenuity often has to be exercised in the synthesis of specimens free from troublesome and persistent impurities. The chemical purification of $n$-pentanol and the synthesis of $m$-ethylphenol illustrated some facets of this work. Purification techniques now being used include fractional distillation and freezing, zone melting and sublimation. Purity control is by gas chromatography, mass spectrometry, differential thermal analysis, cryoscopy and high-resolution nuclear magnetic resonance spectroscopy. The above-mentioned techniques are also used to prepare and certify pure materials as 'Standard Samples'. This work was illustrated by the purification of fatty acids for the synthesis of higher paraffins and by the synthesis of compounds in the indane series. An apparatus for ampouling pure gaseous and liquid samples was on display. National Chemical Laboratory Standard Samples supplied by this Group are purchased by industry at the rate of about 400 per year for the calibration of mass and other spectrometers which are in use for the analysis of chemical plant streams.

E. A. Coulson

\title{
BROOM'S BARN EXPERIMENTAL STATION
}

\author{
By DR. R. HULL
}

$\mathrm{O}$ $\mathrm{N}$ July 27, the Minister of Agriculture, Fisheries and Food, the Right Hon. Christopher Soames, formally opened Broom's Barn Experimental Station, Higham, Bury St. Edmunds, Suffolk, in the presence of about 250 guests. The Right Hon. the Earl of Radnor, chairman of the Lawes Agricultural Trust Committee, welcomed the Minister and invited him to open the Station, and Sir Peter Greenwell, chairman of the Sugar Beet Research and Education Committee, thanked the Minister.

Broom's Barn farm was acquired in 1959 by the Lawes Agricultural Trust Committee, the governing body of Rothamsted Experimental Station, and has been developed as a research station to study sugar beet growing. The land, new farm buildings and laboratories have been paid for by grants amounting to nearly $£ 250,000$ from the Ministry of Agriculture's Sugar Beet Research and Education Fund, to which both sugar beet growers and the British Sugar Corporation, Ltd., subscribe.

Broom's Barn Experimental Station replaces the Rothamsted Field Station, Dunholme, near Lincoln, where rosearch for the Sugar Beet Research and Education Committee has been carried out since 1947. Work on diseases of sugar beet, which began at Hackthorn in Lincolnshire in 1935 in association with the Midland Agricultural College, became a charge of Rothamsted Experimental Station after the Second World War and a field station was established in temporary buildings on a disused airfield at Dunholme. The work extended to include the manuring and pests of sugar beet, but was handicapped by lack of land and suitable buildings.

The ultimate aim of all the work is to improve the health and yields of both the root and seed crops. To this end, field experiments and observations, supported by the necessary glasshouse and laboratory work, are made to elucidate the biology of pests and pathogens, to assess the damage they cause, and to find how the losses can be lessened. The research workers co-operate closely with the field staffs of the sugar factories in field experiments, in recording the incidence of pests and diseases, in organizing a spraywarning scheme to advise growers when to spray the crops against aphids that threaten to spread yellows, and in the certification of mangold and sugar beot stecklings.

The work on manuring aims at ensuring that fertilizers are used most efficiently and economically. Each year many field experiments, performed in conjunction with the British Sugar Corporation, test responses to a range of fertilizers applied in different ways. Laboratory methods of forecasting these responses are investigated. This work will continue and be expanded at Broom's Barn, where it will also be possible to do long-term experiments on the effect of fertilizers, cultivations, crop rotations and agricultural chemicals (weed killers, insecticides and fungicides), and to study irrigation of sugar beet.

\section{The Buildings}

The new buildings consist of an administrative block with offices, library, meeting hall and mess room ( 3,740 sq. ft.), chemistry and biological laboratories $(4,040$ sq. ft.), field laboratories (3,700 sq. ft.), tarehouse $(3,000 \mathrm{sq}$. ft.), glasshouses $(2,830 \mathrm{sq}$. ft. $)$, cloakrooms (790 sq. ft.), circulation areas (1,650 sq. ft.) and a service block (2,160 sq. ft.). There are five cottages for Staff and a house for the Head of the Station (Dr. R. Hull).

The buildings were designed by Cowper, Poole and Partners, Chartered Architects, to blend into the open Suffolk landscape. The choice of the traditional rural pantiles as roofing set limits on the pitch of roofs and width of buildings. The layout of the buildings and their interior design give flexibility and allow for expansion should this prove necessary. The service mains within the buildings are at high level and have a 'fishbone' layout, so that they are easily accessible and altered. The courts between buildings give sheltered outside working space-a boon on this windswept exposed site.

In the administrative building the offices occupy the south side, the library, mess room and cloakroom the north and the meeting hall lies between them. This airy hall, with underfloor heating, will seat more than 200 people. It will be used only occasionally for such large audiences, so the furnishings have been designed to divide it into parts suitable for small conferences, staff meetings or demonstrations.

The laboratory building provides a large chemistry and a biology laboratory with eight smaller laboratories on the south side. The north-facing, large laboratories are lit by the south-facing clerestory windows. The circulation area is cut off from the laboratory only by pillars, an arrangement which avoids tunnellike corridors. There are a photographic studio and dark room, balance room, chemical dark room, inoculation room and medium room and main store.

The field laboratory is the same basic construction as the main laboratory, but has a cheaper finish. 


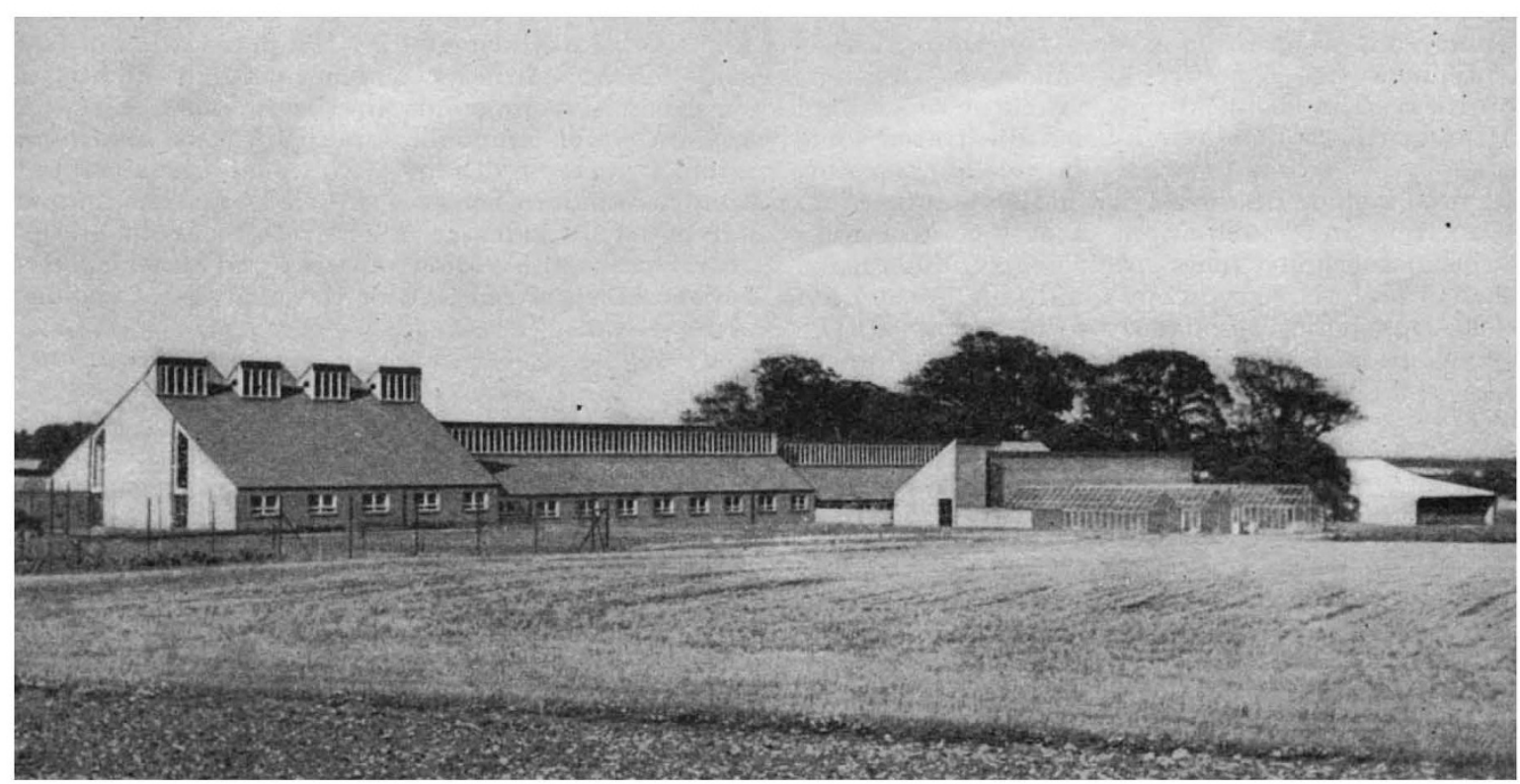
Fig. 1. View of Broom's Barn Experimental Station from the south-west. From left to right are the administrative building, laboratories,
feld laboratories, and tarehouse. In front of the latter is the headerhouse with four compartmented glasshouses. On the right, among the trees, are the farm buildings

It contains a room for preparing and storing pottingsoil, a soil-sample store, an area for drying, treating and storing seed, a general reception area and a laboratory.

The adjoining tarehouse has the sample reception and storage platform at high level and the machinery at low level. The two washers use recirculated water from a settling pond situated near the farm buildings. One of the spray washers serves an automatic line in which the roots are not handled after being tipped into the washer hopper; from the other, the roots are delivered to baskets on roller conveyors so they can be examined, topped, otc., after washing. Both lines feed a multiple saw, and the dross is delivered into a lorry or heap outside. The brei from the saws goes for test of sugar content and juice purity into the adjacent tarehouse laboratory, which is part of the field laboratory.

\section{The Farm}

The farm lies 230-280 ft. above sea-level and consists of 190 acres in a rectangle approximately $1,200 \mathrm{yd}$. by $770 \mathrm{yd}$. The soil is glacial deposit over chalk. On the north side of the farm it is light and sandy (Moulton and adjoining series) grading through medium loam with flints (Newmarket and Ashley series) to a heavy loam (Stretham series) as the land rises to the south.

The old farm dirt tracks have been ploughed and a concrete road laid to give access to the farm buildings and to all fields. There is a concrete beet-loading platform at the south end of the farm. All but one of the eleven fields into which the farm has been divided are roughly rectangular and most boundaries are parallel to the sides of 5-chain grid squares, marked by permanent sockets around the farm boundary. Soil samples have been taken from each square chain, analysed for available phosphorus, potassium, $p \mathbf{H}$ and organic matter and stored for future reference.

A 5-in. irrigation main runs the length of the farm, and temporary surface mains can be taken from hydrants to irrigate any part. The water is pumped electrically from a $400 \mathrm{ft}$. borehole near the farm buildings, which yields more than 12,000 gallons per hour, enough to irrigate 2 acres at a time, and also supplies the buildings. The pumping mechanism is arranged so that experimental watering can be done from the irrigation main at a delivery rate much lower than that needed for farm crop irrigation.

The farm buildings are surrounded by a concrete apron. The old timber Broom's Barn is used for storage, and a new genera] purpose building $(2,250$ sq. yd.) is used for machinery, workshop and storage. A new covered cattlo yard ( $6,750 \mathrm{sq}$. ft.) has a centrally placed self-fed silage silo for feeding 80 bullocks in winter. The pumphouse, tarehouse settling pond and sewage plant are near the farm buildings.

The current farming system aims to get the land into good condition for experiments. The basic crop rotation is sugar beet, three cereals and temporary ley, but each field in turn carries a silage crop for cutting in June, after which it is fallowed. This will help to free the land of a heavy weed infestation.

At present, the sugar beet crop provides the site for annual experiments on the control of downy mildew (Peronospora schachtii), chemical weed control, the use of insecticides as seed dressings, soil applications and sprays for controlling aphids and virus yellows, testing and selecting yellows-tolerant varieties and the effect of nitrogen and sowing date on yield. Experiments on the cereal crops determine nitrogen responses. When the land is clean and in good condition, long-term experiments will be started. The experiments will be designed to investigate sugar beet as a crop of the rotation and determine how treatments applied to it affect following erops and how treatments applied to previous crops affect the sugar beet. A subject of immediate importance for investigation is the sugar percentage and juice purity of beet, both of which have decreased as the yield of beets and sugar have increased in recent years. 